Short Communication

\title{
Cytogenetics of two hylid frogs from Brazilian Cerrado
}

\author{
Cíntia Pelegrineti Targueta ${ }^{1}$ (D) , Vinícius Guerra ${ }^{2}$, Priscilla Guedes Gambale ${ }^{2}$, Rogério Pereira Bastos ${ }^{3}$, \\ Daniela de Melo e Silva ${ }^{4}$ (D) and Mariana Pires de Campos Telles ${ }^{1,5}$ \\ ${ }^{1}$ Laboratório de Genética \& Biodiversidade, Departamento de Genética, Instituto de Ciências Biológicas, \\ Universidade Federal de Goiás, Goiânia, GO, Brazil. \\ ${ }^{2}$ Programa de Pós-Graduação em Ecologia de Ambientes Aquáticos Continentais, Universidade Estadual de \\ Maringá, Maringá, PR, Brazil. \\ ${ }^{3}$ Departamento de Ecologia, Instituto de Ciências Biológicas, Universidade Federal de Goiás, Goiânia, GO, \\ Brazil. \\ ${ }^{4}$ Laboratório de Mutagênese, Departamento de Genética, Instituto de Ciências Biológicas, Universidade \\ Federal de Goiás, Goiânia, GO, Brazil. \\ ${ }^{5}$ Escola de Ciências Agrárias e Biológicas, Pontifícia Universidade Católica de Goiás, Goiânia, GO, Brazil.
}

\begin{abstract}
Cytogenetic data can be useful for taxonomic and phylogenetic studies, as well as to provide information about chromosome evolution. Therefore, it may help design conservation priorities for some threatened species, such as anurans. Herein, we describe the karyotypes of Scinax constrictus and Ololygon centralis, native endemic species from the Brazilian Cerrado. Chromosome preparations for both species were stained with Giemsa for morphological analyses and then impregnated by the Ag-NOR method for localization of the nucleolar organizer region (NOR). Both species had 24 chromosomes, as confirmed by meiotic analyses, which showed 12 bivalents. Chromosome morphologies presented the same pattern for Scinax and Ololygon compared to species already karyotyped in both genera. The NOR was interstitially located in the long arm of pair 7 in $S$. constrictus, whereas in $O$. centralis it was found near the centromere in the long arm of pair 1, thus diverging from what is commonly found for other Ololygon species. Therefore, we provide the first description of the karyotype of $O$. centralis and the first report of the localization of the NOR for the karyotype of both species. Our study increases the cytogenetic knowledge in species of the genera Scinax and Ololygon, and provide support for further studies on the taxonomy, ecology, and evolution of hylid anurans.
\end{abstract}

Keywords: Anura, karyotype, Ololygon, Scinax.

Received: December 25, 2017; Accepted: April 10, 2018.

The tree frog family Hylidae is the richest in number of species among anurans, with 716 described species (Frost, 2018). It comprises seven subfamilies: Acridinae (21 spp.), Comphomantinae (185 spp.), Dendropsophinae (107 spp.), Hylinae (167 spp.), Lophyohylinae (85 spp.), Pseudinae (13 spp.), and Scinaxinae (137 spp.). Scinaxinae comprises now four genera: Julianus (2 spp.), Ololygon (48 spp.), Scinax (72 spp.), and Sphaenorhynchus (15 spp.) (Duellman et al., 2016). The Ololygon species were previously considered to belong to the genus Scinax, in the Scinax catharinae clade, while species that remained in the genus Scinax comprise the Scinax ruber clade (Faivovich,

Send correspondence to Cíntia Pelegrineti Targueta. Laboratório de Genética \& Biodiversidade, Departamento de Genética, Instituto de Ciências Biológicas, Universidade Federal de Goiás, Estrada do Campus, s/n, Campus Samambaia, Goiânia, GO, Brazil. Zip code: 74690-900. E-mail: cincintia@ hotmail.com
2002; Faivovich et al., 2005). The species of Scinaxinae are distributed throughout Central and South America, from southern and eastern Mexico to Uruguay and northern Argentina (Frost, 2018).

Knowledge on chromosome number and morphology of hylids is still sparse, and in Scinaxinae, only 45 species of the genera Scinax and Ololygon have known karyotypes (Peixoto et al., 2015, 2016). The karyotypes of Scinax and Ololygon analyzed so far are very conservative concerning the diploid number $(2 \mathrm{n}=24)$, although morphological patterns can be discerned among them (Bogart, 1973; Nunes and Fagundes, 2008; Oliveira et al., 2010; Cardozo et al., 2011; Nogueira et al., 2015; Peixoto et al., 2015). The localization of the nucleolar organization region (NOR) and the heterochromatic pattern were described for most of the species analyzed. For most of them, the NOR was observed on chromosome pair 11 for Scinax species and on pair 6 for 
Ololygon species (species previously grouped in the Scinax catharinae clade by Faivovich et al., 2005) (Cardozo et al., 2011), and C-banding patterns were predominantly centromeric (Cardozo et al., 2011; Peixoto et al., 2015).

The Scinax rostratus group was recognized by Faivovich et al. (2005), in which Scinax constrictus is allocated (Lima et al., 2004). Pombal-Jr and Bastos (1996) described Ololygon (=Scinax) centralis and allocated it inside the Scinax catharinae group according to its morphological and acoustic data. Both species are endemic to the Brazilian Cerrado, which is considered a biodiversity hotspot, with high levels of endemic species, most of them being threatened by anthropic activities (Myers et al., 2000; Mittermeier et al., 2005). In addition, the Cerrado has been reported to house $52 \%$ of endemic anuran species (Valdujo et al., 2012). Although several studies have demonstrated the recent degradation and loss of biodiversity (Beuchle $e t$ al., 2015; Françoso et al., 2015), many species have been described for this biome (e.g., Berneck et al., 2017; Haga et al., 2017).

Little is known about the cytogenetics of frogs in the Cerrado. An increase in knowledge, therefore, may help to improve studies on the taxonomy, phylogeny, and evolution of anurans in this threatened biome. Herein, we describe the chromosome number and NOR pattern in several populations of Scinax constrictus and Ololygon centralis, two endemic hylids from the Brazilian Cerrado.

The field work was conducted at three different localities of the Cerrado (Figure 1; Table S1). We used the sampling method involving visual and acoustic searches (Heyer et al., 1994) to find the individuals. After being found, we captured the individuals with our hands and carefully placed them in plastic bags, and later they were maintained in a Styrofoam box for transport to the laboratory. Individual specimens received an application of colchicine and after four hours, specimens were euthanized with 5\% lidocaine. The liver and tissues from the hind paw muscles, intestine, and glands were removed for molecular analysis. Subsequently, each specimen was fixed with $10 \%$ formalin, preserved in $70 \%$ alcohol, and deposited in the Coleção Zoológica of the Universidade Federal de Goiás (ZUFG), Brazil (Table S1). Sampling dates, capture and species collection were authorized under a license granted by the Instituto Chico Mendes de Conservação da Biodiversidade, Brazil, (ICMBio; number 46522-3), and the experiments were authorized by the Comitê de Ética ao Uso de Animais of the Universidade Federal de Goiás (number 109/14).

We captured samples of Scinax constrictus and Ololygon centralis. S. constrictus (Lima et al., 2005) is a small-sized hylid $(26.09 \pm 1.83 \mathrm{~mm}$ for males, $31.93 \pm 2.53$ $\mathrm{mm}$ for females; Lima et al., 2005) distributed in the Brazilian states of Goiás, Tocantins, Minas Gerais, and Mato Grosso do Sul (Frost, 2017). The reproduction of this species occurs during the rainy season (September-February) in the Cerrado Biome (Gambale et al., 2014). Males may be

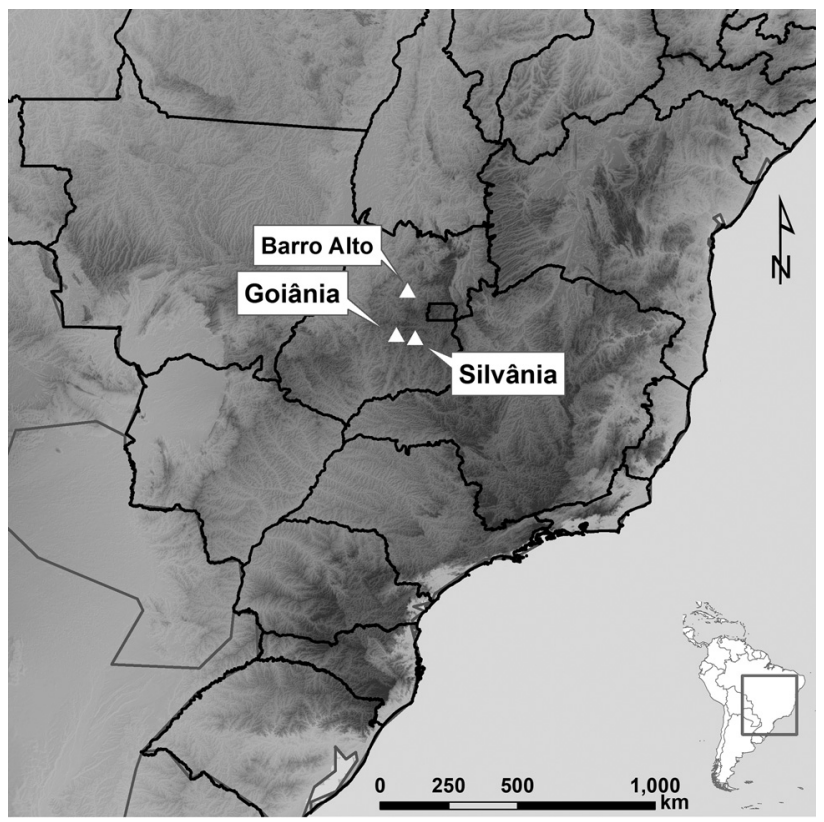

Figure 1 - Geografic view of Scinax constrictus and Ololygon centralis sampled sites. Scinax constrictus were collected at Barro Alto and Goiânia, GO. Ololygon centralis were found at its type-locality, Floresta Nacional de Silvânia, Silvânia, GO

found in lentic water bodies and the social behavior is mediated mainly by acoustic signals (Gambale et al., 2014). Information on some aspects on the ecology of this species can be found in the studies of Lima et al. (2005) and Gambale et al. (2014). Males of $S$. constrictus were collected at two distinct sites: four males were from Barro Alto, Goiás (ZUFG9310, ZUFG9311, ZUFG9312, ZUFG9319) and 10 males from Goiânia, Goiás (ZUFG8715, ZUFG8716, ZUFG8717， ZUFG8718, ZUFG8719, ZUFG8720, ZUFG8721, ZUFG8722, ZUFG8723, ZUFG8724).

Ololygon centralis (Pombal and Bastos, 1996) is a small-sized hylid frog (19.74 $\pm 0.87 \mathrm{~mm}$ for males; Pombal-Jr and Bastos, 1996) distributed in the Distrito Federal and Goiás State, Brazil (Frost, 2017). The reproduction of this species occurs mainly during the rainy season (January-April) in the Cerrado Biome (Bastos et al., 2011). Males may be found in lotic water bodies, and the social behavior is mediated by acoustic signals (Bastos et al., 2011). Eleven specimens of $O$. centralis were collected, of which four were females (ZUFG9294, ZUFG9301, ZUFG9303, ZUFG9304) and seven were males (ZUFG9295, ZUFG9296, ZUFG9297, ZUFG9298, ZUFG9299, ZUFG9300, ZUFG9302) from the type-locality Floresta Nacional de Silvânia (FLONA), Silvânia, Goiás, Brazil.

Chromosome preparations were obtained from intestinal and testis cells of the animals previously treated with colchicine for 4 hours following the method of Schmid (Schmid, 1978; Schmid et al., 1979) with minor modifications. The cells were maintained at $-20^{\circ} \mathrm{C}$. For morphologi- 
cal analyses, the cell suspensions were dropped onto clean slides and submitted to conventional staining with $10 \%$ Giemsa. The localization of the nucleolar region was detected by the Ag-NOR method described by Howell and Black (1980). Mitotic and meiotic chromosomes were photographed under a Leica microscope and with the LAS EZ software (Leica). The chromosomes were ordered with Photoshop CS5 and classified following Green and Sessions (1991).

After analyses, all males of $S$. constrictus showed a diploid number with 24 chromosomes. Mitotic chromosome pairs $1,2,9,10,11$, and 12 were characterized as metacentric, while the chromosome pairs 3, 4, 5, 6, 7, and 8 were characterized as submetacentric (Figure 2, Table 1). The NOR was detected at the interstitial region of the long arm of pair 7 , in the same place where a secondary constriction is presented (Figure 2). The diploid number was confirmed by the presence of 12 bivalents in the meiotic preparations (Figure 2). In addition, all specimens of $O$. centralis, i.e., both the males and females, showed $2 n=24$ chromosomes, in which the pairs $1,2,3,4,5,6$, and 7 were submetacentric, while pairs $8,9,10,11$, and 12 were metacentric (Figure 3, Table 1). The NOR was detected at the proximal region of the long arm of pair 1 (Figure 3 ). The

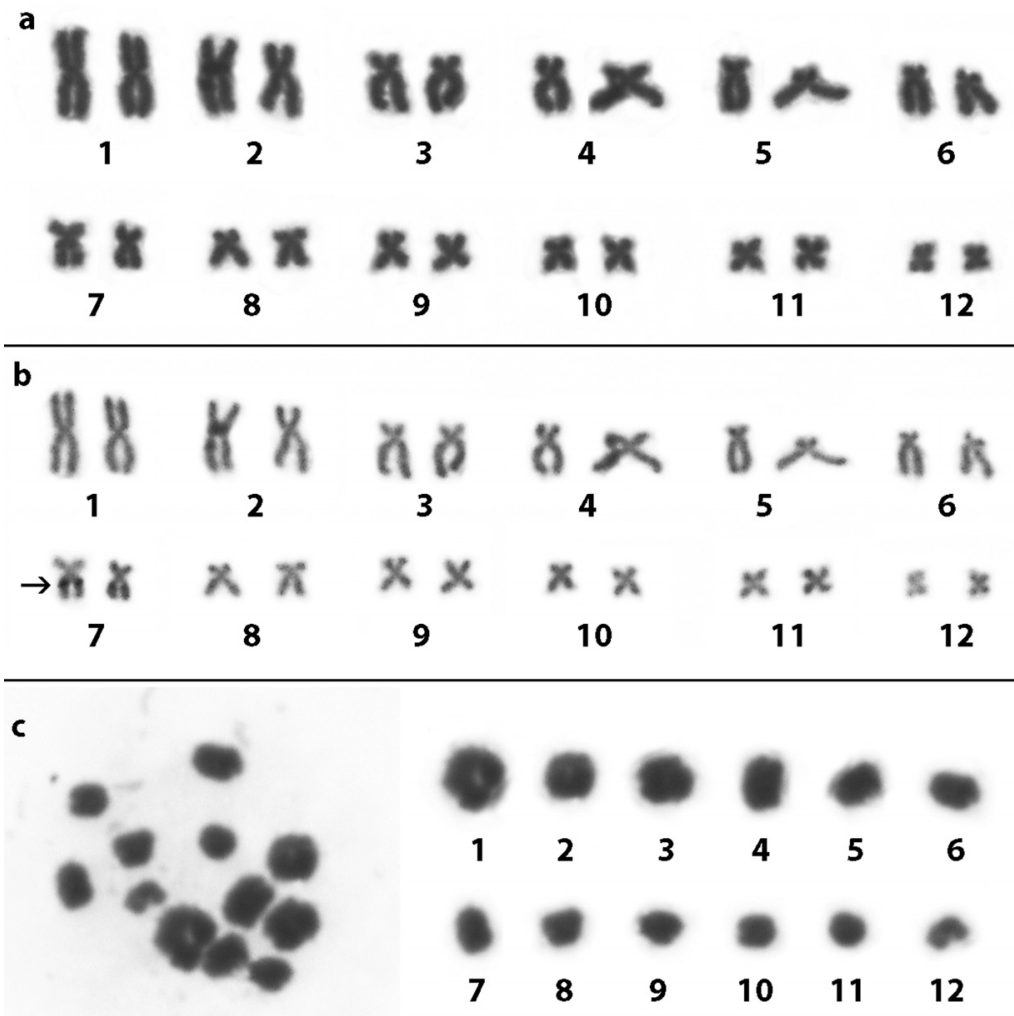

Figure 2 - Karyotype of Scinax constrictus (ZUFG8715) stained with 10\% Giemsa (a), Ag-NOR impregnation (ZUFG9310) (b) and meiotic bivalents (ZUFG8718) (c) The arrow in (b) shows the localization of the NOR.

Table 1 - Morphometric parameters of Scinax constrictus and Ololygon centralis karyotypes. Chromosome classification followed Green and Session (1991). (m) metacentric; (sm) submetacentric; (st) subtelocentric; (t) telocentric.

\begin{tabular}{lcccccccccccc}
\hline \multicolumn{10}{c}{ Scinax constrictus } \\
\hline Chromosome number & 1 & 2 & 3 & 4 & 5 & 6 & 7 & 8 & 9 & 10 & 11 & 12 \\
Relative Length (\%) & 13.20 & 11.65 & 10.85 & 9.89 & 9.04 & 8.27 & 7.85 & 7.06 & 6.31 & 5.96 & 5.40 & 4.52 \\
Arm ratio & 1.32 & 1.56 & 1.75 & 2.30 & 2.34 & 2.14 & 1.98 & 1.86 & 1.40 & 1.38 & 1.29 & 1.24 \\
Classification & $\mathrm{m}$ & $\mathrm{m}$ & $\mathrm{sm}$ & $\mathrm{sm}$ & $\mathrm{sm}$ & $\mathrm{sm}$ & $\mathrm{sm}$ & $\mathrm{sm}$ & $\mathrm{m}$ & $\mathrm{m}$ & $\mathrm{m}$ & $\mathrm{m}$ \\
\hline Chromosome number & 1 & 2 & 3 & 4 & 5 & 6 & 7 & 8 & 9 & 10 & 11 & 12 \\
Relative Length (\%) & 11.58 & 10.64 & 9.92 & 9.56 & 9.22 & 8.98 & 8.47 & 7.93 & 7.21 & 6.08 & 5.56 & 4.85 \\
Arm ratio & 2.94 & 2.65 & 2.48 & 2.38 & 2.22 & 2.13 & 2.17 & 1.60 & 1.31 & 1.33 & 1.28 & 1.31 \\
Classification & $\mathrm{sm}$ & $\mathrm{sm}$ & $\mathrm{sm}$ & $\mathrm{sm}$ & $\mathrm{sm}$ & $\mathrm{sm}$ & $\mathrm{sm}$ & $\mathrm{m}$ & $\mathrm{m}$ & $\mathrm{m}$ & $\mathrm{m}$ & $\mathrm{m}$ \\
\hline
\end{tabular}




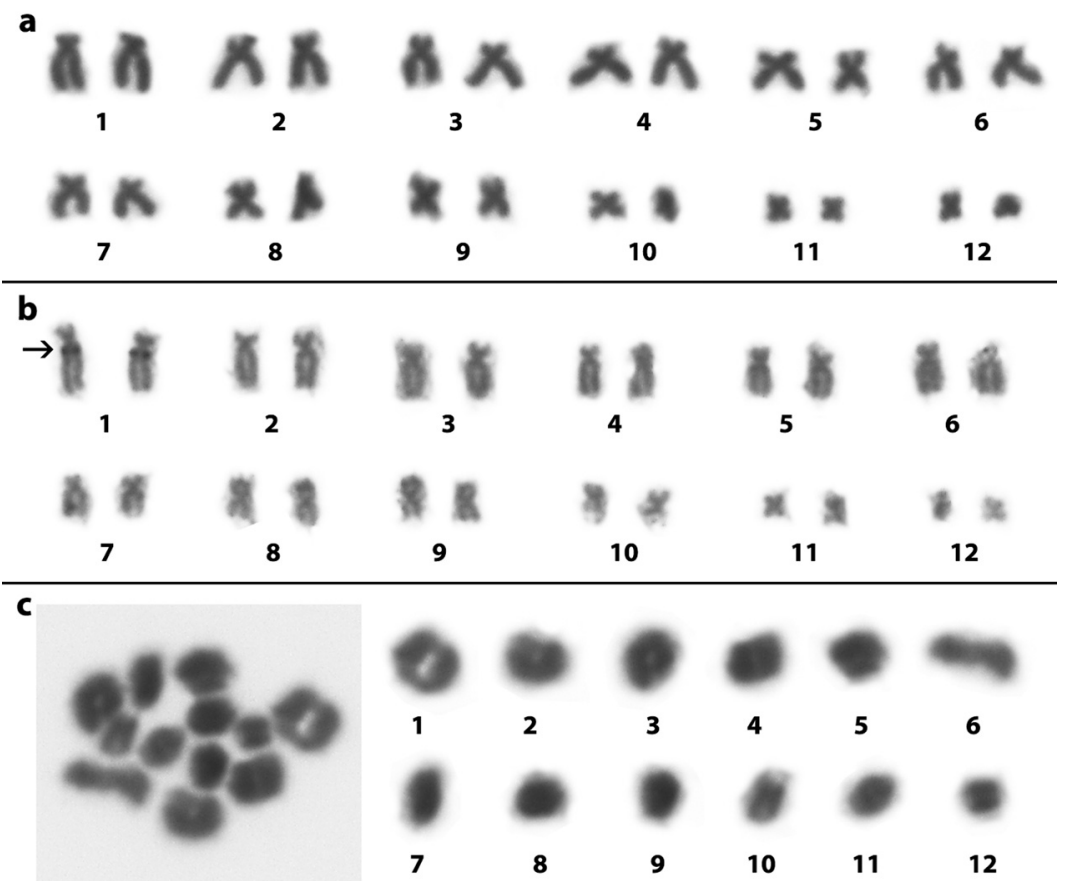

Figure 3 - Karyotype of Ololygon centralis (ZUFG9300) stained with 10\% Giemsa (a), Ag-NOR impregnation (ZUFG9304) (b) and meiotic bivalents (ZUFG9295) (c) The arrow in (b) shows the localization of the NOR.

diploid number was confirmed by the presence of 12 bivalents in the meiotic preparations (Figure 3).

The diploid number $(2 \mathrm{n}=24)$ described for $S$. constrictus and for $O$. centralis is the same number previously described for species of both genera (Bogart, 1973; Nunes and Fagundes, 2008; Oliveira et al., 2010; Cardozo et al., 2011; Nogueira et al., 2015; Peixoto et al., 2015). Within the Scinaxinae family, as proposed by Duellman et al. (2016), the diploid number seems to be conserved $(2 \mathrm{n}=24)$, changing only for Sphaenorhyncus caramaschii (Suárez et al., 2013), which shows a karyotype composed of 26 chromosomes. However, the diploid number also differs when compared to closely related species to Scinaxinae (Duellman et al., 2016), such as those of the genera Phyllodytes and Scarthyla with 2n=22, Aparasphenodon, Trachycephalus, Itapotihyla, Osteocephalus, Pseudis (except one species with $2 \mathrm{n}=28$ ), and Lysapsus with $2 \mathrm{n}=24$, and the genus Dendropsophus with 2n=30 (Busin et al., 2001, 2006; Kasahara et al., 2003; Gruber et al., 2012; Suárez et al., 2013).

Notably, Oliveira et al. (2010) found only 22 chromosomes for Scinax constrictus, which represents the first report of a different diploid number within the genus, suggesting a case of population variation. However, the chromosomal morphology was very similar to that found in the present study. Hence, this improved knowledge on the population cytogenetics will contribute with the elucidation of the possible evolutionary differentiation among populations of $S$. constrictus. Moreover, the chromosome morphology assigned for Scinax (= Scinax ruber clade) and
Ololygon (= Scinax catharinae clade) by Bogart (1973) was also now detected for $S$. constrictus and O. centralis, respectively, as well as in some other previous studies (Oliveira et al., 2010; Cardozo et al., 2011; Nogueira et al., 2015; Peixoto et al., 2015, 2016; Lourenço et al., Gruber et al., 2017). All these findings demonstrate that chromosomal morphology is a conserved feature in both of these Scinaxinae genera.

The nucleolar organizer region (Ag-NOR) was localized herein for the first time for the karyotypes of $S$. constrictus and $O$. centralis. It was detected in the long arm of pair 7 in $S$. constrictus, thus differing from previous data for Scinax and Julianus species (previously, Scinax ruber clade), where they are found in the short arm of pair 11 (Cardozo et al., 2011; Nogueira et al., 2015; Peixoto et al., 2016; Gruber et al., 2017). Notably, the NOR was also found in this same chromosome pair in phylogenetically more distant species, such as those of the genera Xenohyla, Lysapsus, and Pseudis (except for one population). In those cases, the chromosome was morphologically similar to the pair 7 of Scinax constrictus (Busin et al., 2001, 2006; Suárez et al., 2013). In addition, the position of the NOR found in $S$. constrictus resembles more that found in species from other genera than in species of Scinax itself, which could represent a plesiomorphic state maintained by $S$. constrictus, or even a resurrected feature during the evolution of the group. In this sense, the increased characterization of the Scinax rostratus group karyotype, in which $S$. constrictus is allocated, should help to further understand the NOR evolution within the Scinaxinae family. 
Most of the Ololygon (= Scinax catharinae clade) species already karyotyped have the NOR localized at the pericentromeric region of the short arm of pair 6 (Cardozo et al., 2011; Peixoto et al., 2015; Gruber et al., 2017). However, the chromosome bearing the NOR in O. centralis is pair 1 . This is the only species within the Scinaxinae subfamily that has the NOR located in this chromosome pair, corresponding to a probable autapomorphy for this species. Moreover, for $O$. caissara, chromosome 2 is the NOR bearing one (Lourenço et al., 2016). Due to the very similar morphology shared by pairs 1 and 2 of Ololygon species, additional studies are needed to conclude whether these two species share the same NOR position, or if this is an acquired, particular evolutionary characteristic.

Despite analyzing males and females, we did not detect any sex chromosomal differentiation or NOR heteromorphism in $O$. centralis. Cardozo et al. (2011) identified one heteromorphic pair related to the presence of the NOR in Ololygon canastrensis. In this case, males and females presented the NOR in the terminal region of the long arm of pair 11, but females had an additional NOR in the short arm of one homologue of pair 6 (Cardozo et al., 2011). In addition, Peixoto et al. (2016) also detected another case of NOR variation in Ololygon tripui, but this was not sex related. In that case, besides the Ag-NOR location in pair 6 of the karyotype, rDNA sites were also evidenced in both the third and the fourth pairs by fluorescence in situ hybridization (FISH). Although a more conserved NOR state in some Anura groups is observed, variations on its position and number are widely described, even between individuals of the same species (Schmid et al., 1995; Silva et al., 1999; Targueta et al., 2010; Bruschi et al., 2013). The presence of multiple NOR sites, even in the same species or populations of organisms, may be explained by several cellular events, such as duplication of repeats, transposition, ectopic recombination, or chromosome rearrangements (Schmid, 1982; Hall and Parker, 1995; LeRiche et al., 2015).

In conclusion, this study reports additional karyotype characteristics of two endemic anuran species from the Brazilian Cerrado Biome. It emphasizes that the chromosome morphology is conserved within both genera, but that they show a specific karyotype organization and NOR location, providing support for the taxonomic changes proposed by Duellman et al. (2016) based on molecular data. However, as the Scinaxinae subfamily is a species-rich group, further studies on the most related species are needed to better understand the evolutionary cytogenetics of this Hylidae taxon.

\section{Acknowledgments}

We received financial support from the programs DOC-FIX/FAPEG 04/2014 for the grants and the fellowship for CPT. VG received a fellowship from Coordenação de Aperfeiçoamento de Pessoal de Nível Superior (CAPES). DMS, RPB, and MPCT have continuously been sup- ported by $\mathrm{CNPq}$ grants and fellowships. Current research has been developed in the context of the National Institutes for Science and Technology (INCT) in Ecology, Evolution and Biodiversity Conservation, supported by MCTIC/CNpq (proc. 465610/2014-5) and FAPEG.

\section{References}

Bastos RP, Alcantra MB, Morais AR, Lignau R and Signorelli L (2011) Vocal behaviour and conspecific call response in Scinax centralis (Anura: Hylidae). Herpetol J 21:43-50.

Berneck BVM, Giaretta AA, Brandão RA, Cruz CAG and Haddad CFB (2017) The first species of Aplastodiscus endemic to the Brazilian Cerrado (Anura, Hylidae). ZooKeys 642:115-130.

Beuchle R, Grecchi RC, Shimabukuro YE, Seliger R, Eva HD, Sano E and Achard F (2015) Land cover changes in the Brazilian Cerrado and Caatinga biomes from 1990 to 2010 based on a systematic remote sensing sampling approach. Appl Geogr 58:116-127.

Bogart JP (1973) Evolution of Anuran Karyotypes. In: Vial JL (ed) Evolutionary Biology of the Anurans. University of Missouri Press, Columbia, pp 337-349.

Bruschi DP, Busin CS, Toledo LF, Vasconcellos GA, Strussman C, Weber LN, Lima AP, Lima JD and Recco-Pimentel SM (2013) Evaluation of the taxonomic status of populations assigned to Phyllomedusa hypochondrialis (Anura, Hylidae, Phyllomedusinae) based on molecular, chromosomal, and morphological approach. BMC Genet 14:70.

Busin CS, Vinciprova G and Recco-Pimentel SM (2001) Chromosomal rearrangements as the source of variation in the number of chromosomes in Pseudis (Amphibia, Anura). Genetica 110:131-141.

Busin CS, Lima AP, Prado CPA, Strüssmann C, Siqueira-Jr S and Recco-Pimentel SM (2006) Chromosomal differentiation of populations of Lysapsus limellus limellus, L.l.bolivianus, and of Lysapsus caraya (Hylinae, Hylidae). Micron 37:355-362.

Cardozo DE, Leme DM, Bortoleto JF, Catroli GF, Baldo D, Faivovich J, Kolenc F, Silva APZ, Haddad CFB and Kasahara S (2011) Karotypic data on 28 species of Scinax (Amphibia: Anura: Hylidae): Diversity and informative variation. Copeia 2:251-263.

Duellman WE, Marion AB and Hedges SB (2016) Phylogenetics, classification, and biogeography of the treefrogs (Amphibia: Anura: Arboranae). Zootaxa 4101:1-109.

Faivovich J (2002) A cladistic analysis of Scinax (Anura: Hylidae). Cladistics 18:367-393.

Faivovich J, Haddad CFB, Garcia PCA, Frost DR, Campbell JA and Wheeler WC (2005) Systematic review of the frog family Hylidae, with special reference to Hylinae: Phylogenetic analysis and taxonomic revision. Bull Am Mus Nat Hist number 294:06-240.

Françoso RD, Brandão R, Nogueira CC, Salmona YB, Machado RB and Colli GR (2015) Habitat loss and the effectiveness of protected areas in the Cerrado Biodiversity Hotspot. Braz J Nat Conserv 13:35-40.

Gambale PG, Signorelli L and Bastos RP (2014) Individual variation in the advertisement call of a Neotropical treefrog (Scinax constrictus). Amphibia-Reptilia 35:271-275. 
Green DM and Session SK (1991) Amphibian Cytogenetics and Evolution. Academic Press Inc., San Diego, 456 p.

Gruber SL, Haddad CFB and Kasahara S (2012) Karyotype analysis of seven species of the tribe Lophiohlini (Hylinae, Hylidae, Anura), with conventional and molecular cytogenetic techniques. Comp Cytogenet 6:409-423.

Gruber SL, Oliveira GIG, Silva APZ, Narimatsu H, Haddad CFB and Kasahara S (2017) Comparative analysis based on replication banding reveals the mechanism responsible for the difference in the karyotype constitution of treefrogs Ololygon and Scinax (Arboranae, Hylidae, Scinaxinae). Comp Cytogenet 11:267-283.

Haga IA, Andrade FS, Bruschi DP and Recco-Pimental, Giaretta AA (2017) Unrevealing the leaf frogs Cerrado diversity: A new species of Pithecopus (Anura, Arboranae, Phyllomedusidae) from the Mato Grosso state, Brazil. PLoS One 12:e0184631.

Hall KJ and Parker JS (1995) Stable chromosome fission associate with rDNA mobility. Chromos Res 3:417-422.

Heyer WR, Donnelly MA, McDiarmid RW, Hayek LC and Foster MS (1994) Measuring and monitoring biological diversity. Standard methods for Amphibians. Smithsonian Institution Press, Washington, $384 \mathrm{p}$.

Howell WM and Black DA (1980) Controlled silver staining of nucleous organizer regions with a protective coloidal developer. Experientia 36:1014-1015.

Kasahara S, Silva, APZ, Gruber SL and Haddad CFB (2003) Comparative cytogenetic analysis on four tree frog species (Anura, Hylidae, Hylinae) from Brazil. São Paulo. Cytogenet Genome Res 103:155-162.

LeRiche K, Eagle SHC and Crease TJ (2015) Copy number of the transposon, Pokey, in rDNA is positively correlated with rDNA copy number in Daphnia obtusa. PLoS One 9:e114773.

Lima LP, Bastos RP and Giaretta AA (2004) A new Scinax Wagler, 1830 of the $S$. rostratus group from central Brazil (Amphibia, Anura, Hylidae). Arq Mus Nac 62:505-512.

Lourenço ACC, Zina J, Catroli GF, Kasahara S, Faivovich J and Haddad CFB (2016) A new species of the Scinax catharinae group (Anura: Hylidae) from southeastern Brazil. Zootaxa 4154:415-435.

Myers N, Mittermeier RA, Mittermeier CG, Fonseca GAB and Kent J (2000) Biodiversity hotspots for conservation priorities. Nature 403:853-858.

Mittermeier RA, Fonseca GAB, Rylands $\mathrm{AB}$ and Brandon $\mathrm{K}$ (2005) A brief history of biodiversity conservation in Brazil. Conserv Bio 19:601-611.

Nogueira L, Paim F, Diniz D, Solé M, Affonso P, Siqueira S and Sampaio I (2015) Cytogenetic analysis of Scinax auratus and Scinax eurdice (Anura, Hylidae) with emphasis on cytotaxonomy. Comparat Cytogenet 9:227-236.

Nunes RR and Fagundes V (2008) Cariótipos de oito espécies de anfíbios das subfamílias Hylinae e Phyllomedusinae (Anura, Hylidae). Bol Mus Biol Mello Leitão do Espírito Santo 23:21-36.

Oliveira HHP, Souza CCN, Ribeiro CL, da Cruz AD, Bastos RP and Silva DM (2010) Citogenética comparativa das famílias Leptodactylidae e Hylidae do Cerrado Goiano. Estudos (Goiânia) 37:725-735.
Peixoto MAA, Lacerda JVA, Coelho-Augusto C, Feio RN and Dergam JA (2015) The karyotypes of five species of the Scinax perpusillus group (Amphibia, Anura, Hylidae) of southeastern Brazil show high levels of chromosomal stabilization in this taxon. Genetica 143:729-739.

Peixoto MAA, Oliveira MP, Feio RN and Dergam JA (2016) Karyological study of Ololygon tripui (Lourenço, Nascimento and Pires, 2009), (Anura, Hylidae) with comments on chromosomal traits among populations. Comp Cytogenet 10:505-516.

Pombal-Jr JP and Bastos RP (1996) Nova espécie de Scinax Wagler, 1830 do Brasil Central (Amphibia, Anura, Hylidae). Bol Mus Nac Nova Ser Zool 371:1-11.

Schmid M (1978) Chromosome banding in Amphibia. I. Constitutive heterochromatin and nucleolus organizer regions in Bufo and Hyla. Chromosoma 66:361-388.

Schmid M (1982) Chromosome banding in Amphibia. VII. Analysis of the structure and variability of NORs in Anura. Chromosoma. 87:327-344.

Schmid M, Olert J and Klett C (1979) Chromosome banding in Amphibia. III. Sex chromosomes in Triturus. Chromosoma 71:29-55.

Schmid M, Feichtinger W, Weimer R, Mais C, Bolaños F and León P (1995) Chromosome banding in Amphibia. XXI. Inversion polymorphism and multiple nucleolus organizer regions in Agalychnis callidryas (Anura, Hylidae). Cytogenet Cell Genet 69:18-26.

Silva APZ, Haddad CFB and Kasahara S (1999) Nucleolus organizer regions in Physalaemus cuvievi (Anura, Leptodactylidae), with evidence of a unique case of Ag-Nor variability. Hereditas 131:135-141.

Suárez P, Cardozo D, Baldo D, Pereyra MO, Faivovich J, Orrico VGD, Catroli GF, Grabiele M, Bernarde PS, Nagamachi CY et al. (2013) Chromosome evolution in Dendropsophini (Amphibia, Anura, Hylinae). Cytogenet Genome Res 141:295-308.

Targueta CP, Rivera M, Souza MB, Recco-Pimentel SM and Lourenço LB (2010) Cytogenetic contributions for the study of the Amazonian Engystomops (Anura; Leiuperidae) assessed in the light of phylogenetic relationships. Mol Phylogenet Evol 54:709-725.

Valdujo PH, Silvano DL, Colli G and Martins M (2012) Anuran species composition and distribution patterns in Brazilian Cerrado, a Neotropical Hotspot. S Am J Herpetol 7:63-78.

\section{Internet resources}

Frost DR (2018) Amphibian Species of the World: an Online Reference. Version $6.0 \mathrm{http}: / /$ research.amnh.org/herpetology/amphibia/index.html (accessed 25 November 2018).

\section{Supplementary material}

The following online material is available for this article:

Table S1 - Data from collected specimens.

Associate Editor: Catarina S. Takahashi

License information: This is an open-access article distributed under the terms of the Creative Commons Attribution License (type CC-BY), which permits unrestricted use, distribution and reproduction in any medium, provided the original article is properly cited. 